\title{
Yüzeyaltı Damla Sulama Yöntemiyle Sulanan Yalova İncisi Sofralık Üzüm Çeșidinde Yaprak Su Potansiyeline Göre Sulama Programının Olușturulması
}

\author{
Gülșen DURAKTEKIN ${ }^{1, *}$ (ID) Yeșim BOZKURT ÇOLAK' ID Kadir KUȘVURAN' ID \\ Mete ÖZFIDANER' ID
}

'Alata Bahçe Kültürleri Araștırma Enstitüsü Müdürlüğü, Mersin

\begin{abstract}
*Sorumlu yazar e-mail (Corresponding author e-mail): gulsenduraktekin@gmail.com
Geliș tarihi (Received): 09.07.2019

Kabul tarihi (Accepted): 19.07.2019

DOI: $10.21657 /$ topraksu.655611
\end{abstract}

Öz

Bu araștırma Çukurova Bölgesinde toprakaltı damla yöntemiyle farklı düzeylerde sulanan Yalova İncisi sofralık üzüm çeșidinde verim ve su kullanım randımanlarını belirlemek amacıyla 2016 yılında Alata Bahçe Kültürleri Araștırma Enstitüsü Müdürlüğü Tarsus Toprak ve Su Kaynakları Topçu İstasyonunda yapılımıștır. Araștırmada 6 farkı sulama düzeyi (Tam sulama, TS; kısıntılı sulama, KS75; Kısıntılı sulama, KS50; PRD75, PRD50 ve Susuz) bulunmaktadır. Tam sulamalarda kök bölgesindeki $(90 \mathrm{~cm})$ eksik toprak neminin tarla kapasitesine getirilmesi öngörülmüștür. Araștırma tesadüf blokları deneme deseninde üç yinelemeli olarak yürütülmüștür. Sulama düzeylerinin verim üzerine etkileri istatistiksel olarak önemli bulunmuștur. En yüksek verim tam sulama (TS) konusunda $30.9 \mathrm{t} \mathrm{ha}^{-1}$, en düșük verim susuz konusunda $11.7 \mathrm{t} \mathrm{ha}^{-1}$ elde edilmiștir. Yaprak su potansiyeli (YSP) ölçümleri mevsim boyunca pressure chamber aleti ile yapıımıștır. Yalova İncisi üzüm çeșidinin gün ortası yaprak su potansiyelinin $\Psi=0.92 \mathrm{MPa}$ değerinde sulanmasıyla en yüksek verim elde edilmiștir. Su stresi arttıkça daha düșük YSP değerleri elde edilmiștir.

Anahtar kelimeler : Asma, sulama programlaması, yaprak su potansiyeli, yüzeyaltı damla sulama

\section{Determination of Irrigation Program with Using Leaf Water Potential in Yalova İncisi Table Grape Variety with Subsurface Drip Irrigation}

\begin{abstract}
This research was carried out in the Eastern Mediterranean Region of Turkey where to determine the effects of various irrigation strategies applied with subsurface drip systems on Yalova İncisi table grape variety and yield and water use efficiency along with optimal irrigation program during 2016, in the experimental fields of Alata Horticultural Research Station, Tarsus Soil and Water Resources Topçu Unit. In the study six irrigation levels (Full irrigation, TS; deficit irrigation, KS75; deficit irrigation, KS50; Partial Root-Zone Drying PRD75\%, Partial Root-Zone Drying PRD50\% of full irrigation treatments and Rainfed, RF) were tested. Soil water deficit in the rootzone depth was replenished to field capacity in irrigations. The experimental was carried out in randomized block design with three replications. The effect of the irrigation levels on the yield were found statistically significant. Full irrigation treatment
\end{abstract}


under the produced the highest yield $\left(30.9 \mathrm{t} \mathrm{ha}^{-1}\right)$, the lowest yield was obtained in rainfed treatment plots $\left(11.7 \mathrm{t} \mathrm{ha}^{-1}\right)$. Leaf water potantial were measured throughout the growing season with a pressure chamber. The YSP values decreased with increasing water stress. Highest yields of Yalova İncisi variety can be obtained when irrigated at leaf water potential value $\Psi=0.92 \mathrm{MPa}$.

Keywords: Grapevine, irrigation scheduling, leaf water potential, subsurface drip irrigation

\section{GíRiș}

Bağ, dünya çapında en yaygın bitkilerden biridir. Ülkemiz, dünya ülkeleri içerisinde bağ alanı bakımından 435000 ha ile 5; yaș üzüm üretimi bakımından ise 4000000 ton ile 6. sırada yer almaktadır (TUIK, 2016).

Türkiye'nin içinde bulunduğu coğrafyanın su kıtlığı, kuraklık ve toprak erozyonu sorunları ile karșı karșıya olması, Türkiyéyi küresel ısınmanın zararlı ve șiddetli etkilerini ilk olarak yașayacak ülkeler arasına sokmaktadır (Doğan, 2005). Küresel ısınmanın en fazla etkileyeceği alanların bașında Akdeniz bölgesi gelmektedir. Yağıșların azalacağı ve sıcaklıkların artacağı göz önünde bulundurulduğunda su kaynaklarının daha verimli kullanılabilmesini sağlayacak yeni yöntem ve teknolojilerin kullanılması gerekmektedir. Su kıtlığının yaygın olduğu kurak ve yarı kurak bölgelerde tarıma ayrılan su miktarından kısıtlama yapmakkaçınılmazhalegelmiștir. Yenigeliștirilmekte olan diğer bir kısıntılı sulama uygulaması da kısmi kök kuruluğu (PRD) uygulamasıdır. Kısmi Kök kuruluğu yönteminde, sulama suyunun alternatif kaynaklardan verilerek bitki kök bölgesinde ıslak ve kuru alanlar olușturulmaktadır. PRD yöntemi birçok tarla bitkisinde ve meyve bahçelerinde denemeler yürütülmüștür (Liu vd., 2003; Davies ve Hartung, 2004; Kang ve Zhang, 2004). Tarla bitkilerinde PRD yöntemiyle uygulanan suyun önemli derecede azaldığını, taç yapısının artığı ve verime diğer sulama yöntemlerine göre daha etkili olduğunu belirtmiștir.

Tarımsal üretim için ayrılan suyun giderek azalması sonucunda, suyun daha etkin ve ekonomik kullanımını sağlayabilmek için farklı sulama yöntemleri geliștirilmiștir. Bu yöntemler içinde de küçük debilerle çalıșan ve su tasarrufu sağlayan düșük basınçlı sulama yöntemleri günümüzde önem kazanmaktadır (Çamoğlu, 2004). Sulama yöntemleri içerisinde, üniform su kullanımı, yüksek randıman, sulama suyu tasarrufu ve ișletme kolaylığı bakımından, özellikle sebze, meyve ağaçları ve süs bitkilerinin sulanmasında damla sulama yöntemleri ön plana çıkmaktadır.
Damla sulama yönteminin farklı uygulama șekilleri bulunmaktadır. Bu uygulama șekillerinden birisi olan yüzeyaltı damla sulama (YAD) yöntemi, özellikle 1990'lı yıllarda Amerika, İsrail, İtalya gibi ülkelerde meyve bahçelerinde, çim ve yem bitkileri gibi çok yıllık bitkilerin sulanmasında kullanılırken, günümüzde ise tüm sebzeleri içerisine alacak șekilde kullanılmaktadır. YAD sisteminde lateraller toprak altına gömülü olduğundan sulama nedeni ile toprak yüzeyinden olan buharlașma ve derine sızma minimize edilmekte, bu nedenle toplam sulama suyu gereksinimi azalmaktadır (Ayars vd., 1999). YAD sisteminde lateraller toprak bünyesi, bitki çeșidi ve ikim șartları dikkate alınarak 3350 cm derinliğe gömülmektedir (Irmak, 2005a). Yüzey altı damla sulama sisteminde bitkinin intiyaç duyduğu besin elementleri sulama suyu ile birlikte direk bitki kök bölgesine verilmektedir.

Sulama programlaması bitkiyi, toprağı ve iklim verilerini kapsamaktadır. Bu sebeple bitkilerde fizyolojik faaliyetler hem toprak hem de çevre koșullarının etkisi altındadır. Toprakta kullanılabilir suyun azalıșına bağlı olarak bitkide fizyolojik olușumlar bozulmakta ve giderek verim düșmektedir. Bu nedenle sulama zamanının saptanmasında toprak suyu eksiliğinden çok bitkisu eksikliğinden yararlanılması önerilmektedir (Tekinel ve Kanber, 1979). Bitkilere ne zaman ne kadar sulama suyu uygulanacağı, bitki izlemeye dayalı yöntemler kullanılarak bitkide su stresinin neden olduğu fizyolojik belirtiler denetlenerek belirlenebilir.

Bitki izlemeye dayalı yöntemlerden yaprak su potansiyeli (YSP) bitki su kapsamına ilișkin etkili bir göstergedir. Son yıllarda geliștirilen bazı cihazlar YSP'nin arazide ölçülmesini kolaylaștırmıștır. Bu yönü ile gerek araștırma gerekse uygulamada YSP birçok bitkide sulama zamanının belirlenmesinde kullanım potansiyeline sahiptir.

Tam sulanan bağlarda gün ortası yaprak su potansiyelinin $(\psi)-10$ bar (-1.0 MPa) değeri "stressiz eșik değer" olarak kabul edilmiștir. «'nin 
-12 bar (-1.2 MPa) ile -14 bar (-1.4 MPa) arasında olması orta derecede stresi, -16 bar (-1.6 MPa) ve daha büyük negatif değerlerin ise așırı stresi temsil ettiği belirtilmiștir (Williams ve Araujo, 2002; Girona vd., 2005).

Bağlarda sulamanın, asmada vejetatif gelișimi, verim ve kaliteyi etkilediğini gösteren çalıșmalar mevcuttur (Dry ve Loveys, 1998; Van Leeuwen ve Seguin, 1994; Pellegrino vd., 2005; Ezzhaouani vd., 2007). Ancak, bu çalıșmalarda sulamanın asmanın șıra ve șarap kalitesi üzerine olan etkisinin hem pozitif, hem de negatif olarak saptanabildiği ve asmanın sulamaya olan yanıtının hasat zamanı, ürün yükü ve su stresinin derecesine bağlı olarak değiștiği görülmektedir.

Bu çalıșmanın amacı Çukurova Bölgesinde yüzeyaltı damla sulama yöntemiyle farklı düzeylerde sulanan Yalova İncisi sofralık üzüm çeșidinde verim ve su kullanım randımanlarının belirlemek ve en uygun sulama programını olușturmaktır.

\section{MATERYAL VE YÖNTEM}

Araștırma 2016 yetiștirme mevsimlerinde, Alata Bahçe Kültürleri Araștırma Enstitüsü Müdürlüğü Tarsus Toprak ve Su Kaynakları Lokasyonu'na bağlı Topçu ișletmesinde yürütülmüștür. Araștırmanın yürütüldüğü bölgede tipik Akdeniz iklimi görülmektedir. Tarsus Araștırma Enstitüsü verilerine göre, bölgenin uzun yıllık yağıș ortalaması 598.1 $\mathrm{mm}$, buharlașma miktarı ise $1480 \mathrm{~mm}$ dir. En fazla buharlașma 216.8 mm ile Temmuz ayında olmaktadır. Uzun yıllar ölçümlerine göre oransal nem ortalaması \%70.3'dür.

Deneme alanının farklı noktalarından alınan bozulmuș ve bozulmamıș toprak örneklerinin analizi sonucunda toprağın bazı özellikleri belirlenmiș ve sonuçlar Çizelgel'de verilmiștir. Deneme alanı toprakları profil boyunca tınlıdır ve $90 \mathrm{~cm}$ profil derinliğindeki kullanılabilir su miktarı 200 mm'dir. Tarla kapasitesi ve solma noktası su içerikleri $90 \mathrm{~cm}$ toprak profilinde derinlik olarak 338 ve 138 mm olarak belirlenmiștir.
Araștırmada 6 farklı sulama düzeyi ele alınmıștır. TS: 7 günlük sulama aralığında 90 cm'lik toprak profilindeki eksik neminin tarla kapasitesine getirildiği konu; KS75: TS konusuna uygulanan suyun \%75'inin verildiği konu; KS50: TS konusuna uygulanan suyun yarısının verildiği konu; PRD50: Her bir sulamada TS konusuna verilen suyun \%50'sinin dönüșümlü olarak bir lateralden uygulandığı konu; PRD75: Her bir sulamada TS konusuna verilen suyun \%75'inin dönüșümlü olarak bir lateralden uygulandığı konu ve SUSUZ: Sulama yapılmayan yağıșa dayalı konu yer almaktadır.

Araștırma, Yalova İncisi sofralık üzüm çeșidi üzerinde tesadüf blokları deneme desenine göre üç yinelemeli olarak yürütülmüștür. Sıra üzeri $1.5 \mathrm{~m}$ ve sıra arası $3.5 \mathrm{~m}$ olup guyot terbiye sisteminde yetiștirilmektedir. Her bir parselde 8 asma $(8 \times 1.5=12 \mathrm{~m})$ bulunmaktadır. Her bir parselin uzunluğu $12 \mathrm{~m}$; parsel alanı ise $3.5 \mathrm{~m} \mathrm{x}$ $12 \mathrm{~m}=42 \mathrm{~m}^{2}$ dir.

Araștırmada damla sulama sistemi kullanılmıștır. Arazi eğimli olduğundan basınç gidericili damlatıcılı lateraller kullanılmıștır. Yüzeyaltı damla sulama sisteminde lateraller toprak yüzeyinin 40-45 cm altına yerleștirilmiștir. PRD konularında lateraller, her bitki sırasının sağına ve solunda bir lateral $80 \mathrm{~cm}$ aralıklarla (bitki sırasının her iki yanında $40 \mathrm{~cm}$ ) olacak șekilde döșenmiștir. PRD konularında, her sulamada yalnızca alternatif bitki sıralarındaki damla lateralleri çalıștırımıștır. İșletme basıncı $2 \mathrm{~kg} \mathrm{~cm}$ cm $^{-2}$ de çalıștırımıștır. Damlatıcı aralığı $40 \mathrm{~cm}$, damlatıcı debisi $2.1 \mathrm{I} \mathrm{h}^{-1}$ olan basınç gidericili damlatıcılar kullanılmıștır. Sisteme su DSi' ye ait sulama kanalından santrifüj pompa ile sağlanmıștır.

Toprak suyu gözlemleri, toprak profilinin ilk katmanında $(0-30 \mathrm{~cm})$ gravimetrik yöntemle, $30-90 \mathrm{~cm}$ arasında ise $30 \mathrm{~cm}$ 'lik artıșlarla nötronmetre yöntemiyle yapıımıs ve hasada dek sürdürülmüștür. Asma bitkisinin 90 cm'lik toprak

Çizelge 1. Araștırma alanı topraklarının bazı fiziksel ve kimyasal özellikleri

Table 1. Physical and chemical properties of different soil layers of the experimental field

\begin{tabular}{ccccccc}
\hline $\begin{array}{c}\text { Katman Derinliği } \\
(\mathrm{cm})\end{array}$ & Bünye Sınıfı & $\begin{array}{c}\text { Tarla Kapasitesi } \\
\left(\mathrm{g} \mathrm{g}^{-1}\right)\end{array}$ & $\begin{array}{c}\text { Solma Noktası } \\
\left(\mathrm{g} \mathrm{g}^{-1}\right)\end{array}$ & $\begin{array}{c}\text { Hacim Ağırlı̆̆ı }(\mathrm{g} \\
\left.\mathrm{cm}^{-1}\right)\end{array}$ & $\mathrm{pH}$ & $\mathrm{EC}\left(\mathrm{dS} \mathrm{m}^{-1}\right)$ \\
\hline $0-30$ & $\mathrm{~L}$ & 24.49 & 12.14 & 1.44 & 7.67 & 0.589 \\
$30-60$ & $\mathrm{SiCL}$ & 27.58 & 9.63 & 1.41 & 7.50 & 0.496 \\
$60-90$ & $\mathrm{C}$ & 28.86 & 11.17 & 1.34 & 7.76 & 0.445 \\
\hline
\end{tabular}


profilinden tükettiği su miktarı, su dengesi eșitliği ile hesaplanmıștır. Su kullanım randımanı (WUE) ve sulama suyu kullanım randımanını (IWUE) belirlemek amacıyla (Howell vd., 1995)'nın verdiği eșitlikler kullanılmıștır.

IWUE $=Y / I$

(Eșitlik 1)

WUEET $=$ Y $/$ ET

(Eșitlik 2)

Bu eșitlikte:

IWUE: Sulama suyu kullanım randımanı $\left(\mathrm{kg} \mathrm{m}^{-3}\right)$;

WUEET: Toplam su kullanım randımanı $\left(\mathrm{kg} \mathrm{m}^{-3}\right)$;

ET: Evapotranspirasyon, (mm);

I: Uygulanan sulama suyu, (mm);

Y: Sulanan konularda elde edilen verimlerdir, $\left(\mathrm{kg} \mathrm{da}^{-1}\right)$

Tüm konulara eșitmiktarda gübre uygulanmıștır. Gözler uyanmadan önce $7 \mathrm{~kg} \mathrm{da-1} \mathrm{N}$; fosfor ve potasyum hesabı ile yaklașı $50 \mathrm{~kg} \mathrm{da}^{-1}$ kompoze gübre (15:15:15:15) uygulaması omcaların her iki tarafından yaklașık $0.5 \mathrm{~m}$ uzakta kalacak șekilde $15 \mathrm{~cm}$ derinliğinde açılan çiziler içerisine gübrenin serpilmesiyle gerçekleștirilmiștir. Tane tutumu döneminde ise azot kaynağı olarak Üre (\%46) ve potasyum kaynağı olarak da potasyum sülfat (\%50 K $\mathrm{O}$ ) kullanılmıș ve bunlar 7'șer kg da-1 saf azot ve potasyum hesabına göre toprağa damla sulama sistemi ile verilmiștir.

Yaprak su potansiyeli (YSP) portatif basınç odacığı (Pressure chamber, Skye SKPM 1400) aygıtı ile gün ortasında (12.00-14.00 arasında) sulama öncesi haftada bir olarak iki yinelemede yapılmıștır. Bu amaçla her parselde bir bitkide tam gelișmiș, güneșe bakan iki yaprakta ölçüm yapılmıș ve bunların ortalaması gün ortası yaprak su potansiyeli değeri olarak alınmıștır. Yaprak su potansiyeli ölçümünde yaprak ayası basınç odacığına sap dıșarıda kalacak șekilde yerleștirilmiș ve aygıtın basınç kaynağından yaprak ayası üzerine basınç uygulanmıș ve sapın dișarıda kalan ucunda su damlası belirinceye dek basınç artırılarak uygulanmıș ve yaprak sapı ucunda su kabarcığı belirdiği andaki değer yaprak su potansiyeli değeri olarak alınmıștır.

Sulama düzeylerinin verim üzerine etkisinin belirlenmesi amacıyla hasatta tüm omcaların verimleri tartılarak konulara göre ortalama omca verimleri belirlenmiștir.

Deneme konularına ilișkin derlenen verilerin istatistiksel analizlerinde JUMP paket programı kullanılmıștır. Ortalamaların karșılaștırılmasında LSD yöntemi uygulanmıștır.

\section{BULGULAR VE TARTIȘMA}

Araștırmada konulara uygulanan toplam sulama suyu miktarları ile deneme konularına ilișkin mevsimsel bitki su tüketimi (ET), verim, su kullanım randımanı (WUE) ve sulama suyu kullanım randımanı (IWUE) değerleri Çizelge 2'de ve ortalama verim değerlerine ilișkin LSD gruplandırması Çizelge 3’de verilmiștir.

Çizelge 2. Araștırmada konulara uygulanan toplam sulama suyu miktarı, mevsimlik bitki su tüketimi (ET), verim, su kullanım randımanı (WUE), sulama suyu kullanım randımanı (IWUE) değerleri

Table 2. The total amount of irrigation water, seasonal evapotranspiration, fruit yield, IWUE and WUE values under different treatments

\begin{tabular}{cccccc}
\hline Sulama Düzeyleri & Verim $\left(\mathrm{t} \mathrm{ha}^{-1}\right)$ & Sulama Suyu $(\mathrm{mm})$ & $\mathrm{ET}(\mathrm{mm})$ & WUE $\left(\mathrm{kg} \mathrm{m}^{-3}\right)$ & IWUE $\left.(\mathrm{kg} \mathrm{m})^{-3}\right)$ \\
\hline TS & $30.9 \mathrm{a}$ & 220 & 472 & $6.54 \mathrm{ab}$ & $14.04 \mathrm{e}$ \\
PRD75 & $29.0 \mathrm{~b}$ & 165 & 427 & $6.80 \mathrm{a}$ & $17.60 \mathrm{c}$ \\
KS75 & $26.9 \mathrm{c}$ & 165 & 422 & $6.37 \mathrm{ab}$ & $16.30 \mathrm{~d}$ \\
PRD50 & $24.8 \mathrm{~d}$ & 110 & 382 & $6.48 \mathrm{ab}$ & $22.52 \mathrm{a}$ \\
KS50 & $23.2 \mathrm{~d}$ & 110 & 376 & $6.17 \mathrm{~b}$ & $21.10 \mathrm{~b}$ \\
SUSUZ & $11.7 \mathrm{e}$ & 0 & 310 & $3.76 \mathrm{c}$ & - \\
\hline
\end{tabular}

$(P<0.01 * *) \% 1$ önemli, $\quad(P<0.05$ *) \% 5 önemli, $\quad(P>0.05$ ö.d. $)$ önemli değil

Çizelge 3. Ortalama verim değerlerine ilișkin LSD gruplandırması

Table 3. LSD grouping on average yield values

\begin{tabular}{cccc}
\hline LSD Gruplandirması & Verim $\left(\mathrm{t} \mathrm{ha}^{-1}\right)$ & WUE $\left(\mathrm{kg} \mathrm{m}^{-3}\right)$ & IWUE $\left.(\mathrm{kg} \mathrm{m})^{-3}\right)$ \\
\hline LSD $(0.05)$ & 1.69 & 0.54 & 0.33 \\
$\mathrm{P}$ & $0.0001^{* *}$ & $0.0001^{* *}$ & $0.0001^{* *}$ \\
CV $(\%)$ & 3.8 & 5.0 & 1.0 \\
\hline
\end{tabular}

$\left(\mathrm{P}<0.01^{* *}\right) \% 1$ önemli, $\quad\left(\mathrm{P}<0.05^{*}\right) \% 5$ önemli, $\quad(\mathrm{P}>0.05)$ önemli değil 
Konulu sulamalara $90 \mathrm{~cm}$ toprak derinliğinde bulunan kullanılabilir suyun \%50'si tüketildiğinde bașlanmıș ve hasattan 13 gün önce sulamalara son verilmiștir. Tüm konulara, 7 gün sulama aralığında toplamda 9 kez sulama yapılmıștır. Deneme süresince konulara uygulanan sulama suyu miktarlarl; TS konusunda 220 mm, PRD75 ve KS75 konularında $165 \mathrm{~mm}$, PRD50 ve KS50 konularında $110 \mathrm{~mm}$ değerleri arasında değișmiștir. Yağıșa dayalı susuz konuya ise su uygulaması yapılmamıștır.

Bitki su tüketiminin hesaplanmasında su dengesi eșitliği kullanılmıștır (Howell vd., 1986). Bitki su tüketim değerleri, sulama konularına göre 310472 mm arasında değișmiștir. Artan sulama suyu ile mevsimlik ET değerlerinde artıș gözlenmiștir. Smart ve Coombe (1983), bağların su tüketiminin 480-530 mm arasında değiștiğini belirtmișlerdir. Gündüz ve Korkmaz (2008), Menemen ovası koșullarında damla sulama sistemi ile sulanan bağ için en yüksek verimi sağlayan konuda uygulanan sulama suyu miktarını 260.5 mm ve su tüketimi değerini de 505 mm olarak belirlemișlerdir.

Hasatta deneme parsellerinden elde edilen meyveler tartılarak kaydedilmiș ve verim değerleri birim alana (ha) dönüștürülerek hesaplanmıștır. Her parselden 6 m uzunluğunda 4 sıra 121 $\mathrm{m}^{2}$ ) hasat edilmiștir. Sulama düzeylerinin verim üzerine etkileri istatistiksel olarak \%1 düzeyinde önemli bulunmuștur. Ortalama olarak üzüm verimleri 11.7-30.9 t ha-1 arasında değișmiștir. En yüksek verim tam sulama (TS) konusundan 30.9 t ha' ${ }^{-1}$, en düșük verim susuz konudan 11.7 t ha $^{-1}$ elde edilmiștir. Șener ve IIlhan (1992) Menemen ve Manisa koșullarında yürüttükleri çalıșmada, önerilen konuda ortalama verim değerini 25.6 t ha ${ }^{-1}$ olarak belirtmișlerdir. Grigorov vd., (2000) yaptıkları çalıșmada, Rusya'da damla sulama ile sulanan bağlara sulama suyu ve sulama sıklığı arttıkça daha yüksek verim elde etmișler. Bağda en yüksek verimi $9.13 \mathrm{t} \mathrm{ha}^{-1}$ tarla kapasitesinin 80-85'e düștüğünde yapılan sulamalardan elde etmișlerdir. Bozkurt Çolak vd., (2014) Adana'da yürüttükleri çalıșmada, en yüksek üzüm verimi TS sulama konusunda (22652.7 $\mathrm{g} \mathrm{omca-1}^{-1}$ ) elde edilmiș bu sırayı PRD75 (20359.4 $\mathrm{g} \mathrm{omca-1}^{-1}$ ), KS75 (18069.4 $\mathrm{g} \mathrm{omca-1}^{-1}$ ), PRD50 (16310.0 $\mathrm{g} \mathrm{omca}^{-1}$ ), KS50 (1 $4527.3 \mathrm{~g} \mathrm{omca-1}^{-1}$ ) konusu takip etmiș ve en düșük verim ise susuz (10734.4 $\mathrm{g} \mathrm{omca}^{-1}$ ) konuda elde edilmiștir. Genel olarak sulamanın verimi olumlu yönde arttırdığı belirlenmiștir.
Su kullanım randımanları (WUE) 3.76-6.54 kg $\mathrm{m}^{-3}$ arasında değișmiștir. En yüksek WUE değeri PRD75 konusunda $\left(6.80 \mathrm{~kg} \mathrm{~m}^{-3}\right)$ elde edilirken, en düșük WUE değeri susuz konudan $13.76 \mathrm{~kg}$ $\mathrm{m}^{-3}$ ) elde edilmiștir. Ağar vd (2010) Adana'da yürüttükleri çalıșmada, en yüksek WUE değeri $31.2 \mathrm{~kg} \mathrm{~m}^{-3}$ ile PRD konusundan, en düșük WUE değeri ise $12.3 \mathrm{~kg} \mathrm{~m}^{-3}$ ile KS50 sulama konusundan elde etmișlerdir.

Sulama suyu kullanım randımanları (IWUE) 14.04-22.52 kg m³ arasında değișmiștir. En yüksek IWUE değeri PRD50 konusundan (22.52 $\mathrm{kg} \mathrm{m}^{-3}$ ) elde edilirken, en düșük IWUE değeri TS konusundan $\left(14.04 \mathrm{~kg} \mathrm{~m}^{-3}\right)$ elde edilmiștir. Genel olarak su kısıntısı arttıkça IWUE değerlerinde bir artıș gözlenmiștir. Șener ve IIIhan (1992) Menemen'de damla sulama ile yürüttükleri çalıșmada, önerilen konu için sulama suyu kullanım randımanını $11.2 \mathrm{~kg} \mathrm{~m}^{-3}$ olarak belirtmișlerdir. Bozkurt Çolak vd (2014) Adana koșullarında damla sulama ile sulanan bağda yaptıkları çalıșmada, en yüksek IWUE değeri yıllara göre sırasıyla $7.77 \mathrm{~kg} \mathrm{~m}^{-3}$, $4.47 \mathrm{~kg} \mathrm{~m}^{-3}$, $8.39 \mathrm{~kg} \mathrm{~m}^{-3}$ olmak üzere PRD50 konusundan elde etmișlerdir.

Yolava İncisi sofralık üzüm çeșidinde sulama konularına göre yaprak su potansiyeli değerlerinin zamansal değișimleri Șekil 1'de verilmiștir. Araștırma yllında anılan değerler TS konusunda -0.80 ile $-1.05 \mathrm{MPa}$; KS75 konusunda -0.91 ile -1.23 MPa; PRD75 konusunda -0.88 ile $-1.18 \mathrm{MPa}$; KS50 konusunda -1.29 ile -1.43 MPa; PRD50 konusunda -1.25 ile $-1.39 \mathrm{MPa}$; SUSUZ konuda ise -1.44 ile -1.70 MPa arasında değișmiștir. TS, PRD75 ve KS75 konularında daha düșük yaprak su potansiyeli değerleri gözlenirken, su stresi altındaki KS50, PRD50 ve SUSUZ konularında daha yüksek yaprak su potansiyeli değerleri belirlenmiștir. Mevsim sonlarına doğru yaprak su potansiyeli değerlerinin göreceli

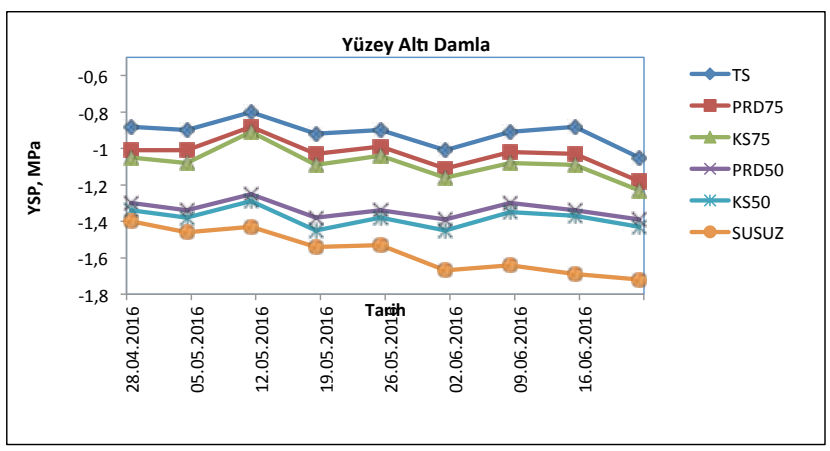

Șekil 1. Yaprak su potansiyeli değerlerinin zamansal değișimi (2016)

Figure 1. Changing leaf water potential values in time (2016) 
olarak daha düșük olduğu görülmüștür. Bu durum yaprakların yașlanması ile açıklanabilir. Bozkurt Çolak (2010) Adana'da yürüttüğü çalıșmada İtalia sofralık üzüm çeșidinde yaprak su potansiyeli değerinin -1.3 MPa ve -1.6 MPa değerinde sulanması ile en yüksek verim elde edilmiștir.

YSP ile verim arasındaki ilișkinin grafiği șekil 2'de verilmiștir. Anılan șekil incelendiğinde, YSP ile verim arasında doğrusal önemli ilișkiler belirlenmiștir. YSP ile verim arasındaki ilișkinin denklemi $Y=24.949$ YSP+ 54.979 RZ=0.85**'dir. Genel olarak düșük ysp değerlerinde daha az verim değerleri elde edilmiștir.

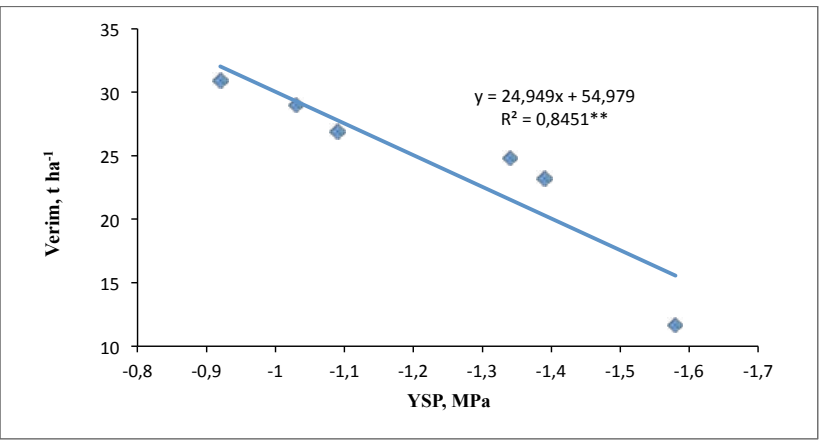

Șekil 2. Yaprak su potansiyeli verim arasındaki ilișki (2016) Figure 2. The relationship between leaf water potential and yield (2016)

\section{SONUÇLAR}

Çukurova Bölgesinde, yüzeyaltı damla sulama yöntemiyle farklı düzeylerde sulanan Yalova İncisi sofralık üzüm çeșidinde verim, bitki su tüketimi ve su kullanım randımanlarının belirlenmesi amacıyla elde edilen çalıșmada, sulamaların verimi arttırdığı görülmektedir.

Deneme yılında, yaprak su potansiyeli değerlerinin sulama konularına bağlı olarak değiștiği gözlemlenmiștir. Su stresi arttıkça daha düșük YSP değerleri elde edilmiștir. Farklı sulama düzeylerine göre elde edilen verim değerleri ile yaprak su potansiyeli değerlerinin birlikte irdelenmesi sonucunda sulama düzeyinin verim üzerine etkisi istatistiksel olarak \%1 düzeyinde önemli bulunmuștur. En yüksek verim tam sulama konusundan ( $\Psi=-0.92 \mathrm{MPa})$ elde edilirken en düșük verim yağıșa dayalı susuz konudan $\mid \Psi=$ -1.58 MPa) elde edilmiștir.

Sonuç olarak, yüzeyaltı damla sulama ile sulanan Yalova İncisi üzüm çeșidinde su kısıntısının olmadığı durumlarda TS konusu, su kısıntısının olduğu durumlarda ise PRD75 konusu önerilmektedir. PRD75 konusunda sudan \%25 tasarruf yapıldığında verimde $\% 7$ azalma görülmüștür.

\section{KAYNAKLAR}

Ağar S (2010). Çukurova koșullarında kısmi kök kuruluğu (PRD) ve kısıntılı damla sulama programlarının Kings Ruby sofralık üzüm çeșidinin verimi, kalite ve su kullanım randımanına etkileri. Yüksek lisans tezi, Çukurova Üniversitesi Fen Bilimleri Enstitüsü, Adana.

Ayars J E, Phene C J, Hutmacher R B, Davis K R, Schoneman R A, Vail S S, Mead R M (1999). Subsurface drip irrigation of row crops: A review of 15 years of research at the water management research laboratory, agricultural water management, 42, 1-27.

Bozkurt Çolak Y (2010). Akdeniz bölgesinde Flame Seedless ve Italıa sofralık üzüm çeșitlerinde yaprak su potansiyeline göre sulama programlarının olușturulması, Doktora tezi, Çukurova Üniversitesi Fen Bilimleri Enstitüsü, Adana.

Bozkurt Çolak Y (2014). Cukurova koșullarında kısmi kök kuruluğu (prd) ve kısıntıı damla sulama programlarının Royal sofralık üzüm çeșidinin verimine ve su kullanım etkinliğine etkileri. TAGEM sonuç raporu, Alata Bahçe Kültürleri Araștırma Enstitüsü Müdürlüğü, Tarsus Toprak ve Su Kaynakları Lokasyonu, Mersin-Tarsus.

Çamoğlu G (2004). Farklı yapım ve yapım özelliklerine sahip damlatıcılarda eș su dağılımının incelenmesi. Yüksek lisans tezi, Çanakkale Onsekiz Mart Üniversitesi Fen Bilimleri Enstitüsü, Çanakkale.

Davies WJ, Hartung W (2004). Has extrapolation from biochemistry to crop functioning worked to sustain plant production under water scarcity? New directions for a diverse planet. In: Proceedings of the 4th international crop science congress. Sept 26- Oct 1 1996, Brisbane, Australia.

Doğan S (2005). Türkiye'nin küresel iklim değișikliğinde rolü ve önleyici küresel çabaya katılım girișimleri. C..ü. İktisadi ve İdari Bilimler Dergisi, 6, 57-73.

Dry P R, Loveys B R (1998). Factors influencing grapevine vigour and the potential for control with partial rootzone drying. Aust. J. Grape Wine Res., 4, 140-148.

Ezzhaouani A, Valancogne C, Pieri P, Amalak T, Gaudille` re J P (2007). Water economy by Italia grapevines under different irrigation treatments in a mediterranean climate. J. Int. Sci., Vigne Vin, 41, 131-140.

Girona J, Mata M, Campo J, Del Arbones A, Baartra E, Marsal J (2005). The use of midday leaf water potential for scheduling deficit ırrigation in vineyards. Irr.

Grigorov MS, Kurapına NV, Malyuga AV (2000). Drip irrigation of vineyards in the volga/don interflue, CAP Abstract, 0335-2591.

Gündüz M, Korkmaz N (2008). Damla sulama ile sulanan bağda farklı sulama uygulamalarının verim ve bazı kalite özelliklerine etkisi. Ege Tarımsal Araștırma Enstitüsü Dergisi, 18 (1) 2008. 
Hook EJ, Kincheloe S (1991). Irrigation scheduling for corn-why and how, University of Florida and C.D. Yonts, University of Nebreska.

Howell TA, Musick JT, Tolk JA (1986). Canopy temparature of irrigated winter wheat. Transactions of the ASAE, Vol. 29(6):1692-1699.

Howell TA, Yazar A, Schneider AD, Dusek DA, Copeland KS (1995). Yield and water use efficiency of corn in response to lepa irrigation. ASAE Trans. of the ASAE, 38(6): 1737-1747.

Irmak S (2005a). A brief research update on subsurface drip irrigation. Available: http://Water.Unl.Edu/ Documents/Subsurface\%20drip\%20irrigation_Irmak_S.Pdf

Kang S Z, Zhang J (2004). Controlled alternate partial root-zone irrigation: Its physiological consequences and impact on water use efficiency. Journal of Experimental Botany, 55(407):2437-2446.

Kanber R (1997). Sulama. C.Ü. Ziraat Fakültesi Genel Yayın No: 174, Adana.

Liu F, Jensen C R, Andersen M N (2003). Hydraulic and chemical signals in the control of leaf expansion and stomatal conductance in soybean exposed to drought stres. Functional Plant Biology, 30(1): 65-73.

Pellegrino A, Lebon E, Simonneau T, Wery J (2005). Towards a simple indicator of water stress in grapevine (vitis vinifera I.) based on the differential sensitivities of vegetative growth components. Aust. J. Grape Wine Res. $11,306-315$
Smart R E, Coombe B.G (1983). Water relations of grapevines. In: T T Kozlowski (Editör), water deficits and plant growth, chapter 4, Academic Pres, New YorkLondon, pp: 137-196.

Șener S, İlhan I (1992). Așağı gediz havzasında yuvarlak çekirdeksiz üzümün su tüketimi ile sulamanın verim ve kaliteye etkileri. Menemen Araștırma Enstitüsü Müdürlüğü Yayınları, Menemen, s.55.

Șimșek M, Gerçek S, Öktem A (2003). farklı sulama yöntemlerinin mısır bitkisinde verim ve su tüketimine etkisi. GAP III. Tarım Kongresi. Bildiri No: S: 29. 2-3 Ekim, Șanlıurfa.

Tekinel O, Kanber R (1979). Çukurova koșullarında kısıntılı su kullanma durumunda pamuğun su tüketimi ve verimi. Tarsus Bölge Toprak Su Araștırma Enstitüsü Müdürlüğü Yayınları, 98:40.

TUiK (2016). Türkiye istatistik kurumu. Available: http:// www.tuik.gov.tr

Van Leeuwen C, Seguin G (1994). Incidences de I'alimentation en eau de la vigne, appre' cie'e par l'e' tat hydrique du feuillage, sur le de'veloppement de l'appareil ve'ge' tatif et la maturation du raisin (vitis vinifera varie' te' cabernet Franc, saint-emilion, 1990). J. Int. Sci. Vigne Vin. 28, 81-110.

Williams LE, Araujo FJ (2002). Correlations among predawn leaf, midday leaf and midday stem water potential and their correlations with other measures of soil and plant water status in vitis vinifera. J. Amer. Soc. Hort. Sci., 127(3):448-454. 